\title{
«ШИРОКА ВІДОМІСТЬ», «ВПЛИВ НА СУСПІЛЬНУ ДУМКУ», «СУСПЫЛЬНА ЗАЦІКАВЛЕНІСТЬ» ТА ІНШІ ОЗНАКИ ПУБЛІЧНОСТІ ФІЗИЧНОЇ ОСОБИ
}

\author{
ЛІСНІЧА Тетяна Володимирівна - кандидат юридичних наук, доцент, доцент \\ кафедри цивільно-правових дисциплін Харківського національного університету \\ імені В.Н. Каразіна \\ УДК 347.15 \\ DOI:10.32782/NP.2020.2.24
}

\begin{abstract}
В статье исследуются гранииь, определяющие публичность физического лича. Представляется, ито определение содержания понятия «публичное бизическое лицо» может варьироваться в зависимости от исполнения им тех или инъхх функиий, в частности - занятие определеннъх государственнъх должностей, исполнение государственнъхх функций, или же занятие определенного места в обществе, ито обусловлено осуществлением таким лицом определенного вида деятельности, не связанной с государственнъми интересами (публичная деятельность, политическая, певческая, актерская и т. д.). Анализируется содержание понятия «иирота влияния публичного физического лица на публичное мнение», а также содержание других категорий, наличие которых позволяет придать лииу статус публичного. В частности, такие, как «широкая известность», «общественная заинтересованность бизическим личом» и другие. В заключительной части автор, в зависимости от изменений в указанных условиях, предлагает вылелить такие категории публичнъгх бизических лич, как «условно публичное» $и$ «истинно публичное».
\end{abstract}

Наділення фізичної особи статусом публічної стає визначною специфічною рисою такої особи, що може істотним чином вплинути як на їі суспільне, так і особисте життя, надати як додаткові права, так і накласти додаткові обов’язки. Публічний статус фізичної особи вимагає окремого дослідження, адже попри широке фактичне поширення осіб такого типу наукова увага дослідженню даного питання майже не приділялась.

Вивченню проблеми правового статусу публічної фізичної особи останнім часом приділяли увагу у своїх дослідженнях такі дослідники, як А.В. Гнатенко, Д.Д. Ауспеник [1], К. Можаровська [4, 5], О.І. Нагнічук $[6,7], \lambda$. Опришко [8], проте деякі критерії визначення ознак публічної особи все ще лишаються не до кінця визначеними та потребують більш глибокого аналізу.

Визначення поняття «публічної фізичної особи» 6 тісно пов'язаним із визначенням меж, що окреслюють публічність такої особи. У попередніх дослідженнях нами було зроблено спробу з'ясувати сутність вказаного терміну, а також проаналізувати його вживання у вітчизняних та міжнародних нормативно-правових актах та правозастосовній практиці [3].

У результаті аналізу було виявлено, що дане поняття є досить неоднорідним, а його правильна кваліфікація вимагає подальшого вивчення.

Зокрема, окремого дослідження, на наш погляд, потребує питання щодо визначення «ступеня публічності» фізичної особи для того, щоб така особа могла бути віднесена до «справді публічних». Зокрема, вимагає додаткового з'ясування теза про те, що саме слід розуміти під «широким колом осіб», яке, за результатами аналізу практики Свропейського суду [8], є однією із ознак, наявність якої обов'язкова для визнання за особою статусу «публічної». 


\section{Цивільне, підприсмницьке, господарське та трудове право}

Як нами було зазначено у попередніх дослідженнях [3], визначення змісту (наповнення) поняття публічної фізичної особи може варіюватися залежно від виконання нею тих чи інших функцій, зокрема, обіймання певних державних посад, виконання державницьких функцій, або ж посідання певного місця у суспільстві, що обумовлене здійсненням такою особою певного виду діяльності, що не пов'язана із державними інтересами (публічна діяльність, політична, співацька, акторська тощо).

Проте, відкритим лишається питання ступеня «широти впливу» та можливого віднесення за цим критерієм представників деяких видів діяльності або професій до публічних осіб із відповідними наслідками, що супроводжують такий статус особи.

Зокрема, йдеться про вчителів, лікарів, викладачів університетів, бізнесменів, коло спілкування яких хоча і $є$ досить широким, проте, чи є достатнім для віднесення представників таких професій до публічних?

Для визначення цього питання, на наш погляд, слід звернутися безпосередньо до розуміння терміну «публічний» та окремо дослідити дефініції та підходи щодо визначення поняття публічної фізичної особи у вітчизняних дослідженнях, міжнародному законодавстві та судовій практиці, а також визначити критерії аудиторії, яка 6 «достатньо широкою» для надання особі статусу публічної.

Академічний тлумачний словник української мови слово «публічний» роз'яснюе як «той, який відбувається в присутності публіки, людей; прилюдний» або «призначений для широкого відвідування, користування; громадський» [11, с. 383]. У попередньому нашому дослідженні ми зазначали, що, таким чином, до публічних слід відносити тих осіб, що є на виду, відкриті для інших людей.

У вітчизняному законодавстві є розповсюдженим вживання терміну «публічний», i, як зазначалось нами раніше [3], зокрема, у ЦК України цей термін вживається у двох значеннях: стосовно віднесення певного виду відносин чи то до приватної, чи то до публічної галузі права, залежно від інтересів, на задоволення яких вони спрямовані та загальноприйняте розуміння слова «публічний», подане у тлумачному словнику.

Вживання терміну «публічний» та близьких до нього зустрічаємо також у багатьох нормативно-правових актах, аналіз яких був проведений у попередніх дослідженнях [3]. Проте в жодному з них не міститься визначення самого поняття того, що слід розуміти під «публічністю» інакше, ніж через наведення прикладів сфер діяльності тих осіб, яких у тому чи іншому випадку пропонується відносити до публічних. Так, до публічних осіб законодавство та судова практика України відносить так званих «національних публічних діячів», «Політично значущих осіб» [9], «службових осіб» [2], «офіційних осіб» [10] тощо.

Таким чином, законодавство та судова практика в Україні публічність фізичної особи переважно пов'язує із обійманням нею певних посад або здійснення певної діяльності, що випливає із виконання функцій, пов'язаних із державою.

Загальноприйнятий європейський підхід розглядає публічність особи більш широко, включаючи до публічних осіб усіх, хто так чи інакше здійснює вплив на «минуле, сучасне або майбутне широкого кола осіб», а також наявність «суспільного інтересу до життя, учинків такої особи у певний період у зв’язку з її діяльністю» [7, с. 348].

Використання більш широкого підходу, на наш погляд, є більш оптимальним та таким, що відбиває реальний стан речей щодо публічності тієї або іншої особи, не обмежуючи та не пов'язуючи таких осіб винятково з особами, що виконують функції держави.

У той же час, деякі ознаки таких осіб $є$ такими, що потребують додаткового уточнення та обговорення.

Так, зокрема, не до кінця зрозумілим лишається, що саме слід вважати «широким» колом осіб, а коло яких осіб можна вважати тим, що будуть достатніми аби інтерес до діяльності особи був визнаний «суспільним».

Визначення цих параметрів дозволить відмежувати статус публічних осіб від тих осіб, діяльність яких хоча, на перший погляд, можливо, і має ознаки публічної, проте не $є$ такою в повному розумінні. Зокрема, це стосується вчителів, викладачів вищих 
навчальних закладів, лікарів та інших осіб, що не підпадають під визначення, надані у перелічених вище нормативних актах та судових рішеннях, проте коло їх спілкування в процесі здійснення діяльності є досить широким внаслідок чого вони можуть як впливати на формування думки широкого кола осіб, так і їхне життя або діяльність може викликати зворотну зацікавленість.

Для цього дослідимо, яких же саме осіб відносять до «публічних» у міжнародному праві та правозастосовній практиці. Як відзначає О. Нагінчук, Верховний Суд СІІА визначає таку класифікацію публічних осіб: 1) особи, що поставили себе в центр певної публічної дискусії з метою впливу на розв'язання обговорюваних питань і стали такими, що визнаються публічними особами для обмеженого кола питань (відносно публічні особи - limited purpose public figures); 2) особи, що здобули славу, сприйняли ролі і займають позиції такої переконливої сили і впливу, що визнаються публічними особами для всіх цілей і в усіх контекстах; 3) особи, що стали публічними без цілеспрямованої діяльності з їхнього боку через участь у резонансній події. У свою чергу, виходячи 3 практики суду СІІА, О. Нагінчук пропонує таких осіб іменувати відповідно: загальними публічними особами, відносними публічними особами та особами, що стали публічними поза своєю волею [6, с. 62].

Видається, основним критерієм, що об'єднує в даній класифікації всіх перелічених осіб є критерій досить «широкої відомості», яка не передбачає особистого знайомства таких осіб із усіма особами, на яких вони «чинять вплив» або у яких «викликають зацікавленість». У той же час, аналіз європейської судової практики вказує на те, що суди в кожному конкретному випадку беруть до уваги обставини, що супроводжували справу, визначаючи, чи можна (слід) визнати особу публічною, визнаючи часом, на перший погляд, публічних осіб непублічними і навпаки (наприклад, справа принцеси Гановерської, справи «Аінгрес проти Австрії», «Фресо і Руар проти Франції», «Таммер проти Естонії» тощо) [8].

Також у літературі ставиться питання щодо віднесення до публічних (i, відповід- но, наділення певними «публічними» обтяженнями осіб, що стали відомими попри своє бажання, в результаті провадження ними повсякденної діяльності. Зокрема, йдеться про відомих успішних бізнесменів, учених, письменників тощо [5, с. 179].

Що стосується останнього аспекту, 3 цього приводу висловлюеться думка про те, що публічність такої особи має визначатися їі свідомим вибором бути чи не бути публічною. При цьому, якщо така особа не виявляє бажання робити публічними всі аспекти свого життя, то публічному обговоренню може підлягати виключно інформація, у зв'язку із якою особа стала відомою. Інші ж аспекти життя такої особи підлягають охороні на загальних підставах [5, с. 179].

Підсумовуючи викладене, вбачається, що основною, так би мовити, «характеристикою» таких критеріїв публічності, як «широка відомість», «вплив на суспільну думку», «суспільна зацікавленість» 6 невизначеність кола осіб, на яких чиниться вплив, або ж яким $\epsilon$ відомим особа, щодо якої визначається іiі публічність. Це, так би мовити, «справжня публічність» - публічність у чистому вигляді.

Особа ж, коло впливу якої ступінь відомості зацікавлених нею інших осіб потенційно можливо окреслити або навіть визначити поіменно, хай навіть їх і буде багато (наприклад, коло впливу вчителя або викладача умовно можна окреслити його учнями або студентами, коло впливу лікаря - пацієнтами тощо) може бути визнана «умовно публічною», оскільки справжня публічність, виходячи $з$ проаналізованих у статті положень, передбачає невизначеність кола осіб.

\section{Мітература}

1. Гнатенко А.В., Ауспеник Д.Д. Право на неприкосновенность частной жизни публичных лиц в контексте диффамационного спора: практические рекомендации // Аичные неимущественные права: проблемы теории и практики применения: сб. статей и иных материалов / под ред. Р.А. Стефанчука. - К.: Юринком Интер, 2010. - 1040 с.

2. Кримінальний кодекс України від 5 квітня 2001 року № 2341-III. - [Електронний ресурс]. - Режим доступу: https://zakon. 
rada.gov.ua/laws/show/2341-14\#n85. - чч. 3,4 ст. 18.

3. Аісніча Т.В. Поняття публічної фізичної особи у законодавстві України. - Порівняльно-аналітичне право. - №2. - 2015. - [Електронний ресурс]. - Режим доступу: http://www.pap.in.ua/2_2015/33.pdf

4. Можаровська К. Захист ділової репутації публічних осіб. [Текст] / К. Можаровська // Юридичний вісник. - 2013. - №3. - c. $140-144$.

5. Можаровська К.В. Зміст категорії «публічна особа» в контексті ії права на захист честі, гідності та ділової репутації. // Науковий вісник Ужгородського національного університету. Серія ПРАВО. - 2013. - Випуск 22.- Частина I. - Том 1 -сс. 178 - 182. - [Електронне джерело]. - Режим доступу: https://dspace.uzhnu.edu.ua/ jspui/bitstream/lib/1275/1/\%D0\%97\%D0\%9 C\%D0\%86\%D0\%A1\%D0\%A2\%20\%D0\%9A \%D0\%90\% D0\%A2\% D0\%95\% D0\%93\% D0\% 9E\%D0\%A0\%D0\%86\% D0\%87\%20\%C2\%AB \% D0\%9F\% D0\%A3\% D0\%91\% D0\%9B\% D0\% 86\%D0\%A7\%D0\%9D\%D0\%90\%20\%D0\%9E \%D0\%A $1 \% \mathrm{D} 0 \% 9 \mathrm{E} \% \mathrm{D} 0 \% 91 \% \mathrm{D} 0 \% 90 \% \mathrm{C} 2 \%$ B B\%20\%D0\%92\%20\%D0\%9A\%D0\%9E\%D0 \%9D\%D0\%A2\%D0\%95\%D0\%9A\%D0\%A1\% D0\%A2\%D0\%86\%20\%D0\%87\%D0\%87\%20 \%D0\%9F\%D0\%A0\%D0\%90\%D0\%92\%D0\%90. pdf c. 179

6. Нагінчук O.I. Правова природа та поняття публічної особи (на основі практики Верховного Суду Сполучених Штатів Америки). // Наукові записки НаУКМА. - 2016. - Том 181: Юридичні науки. -сс. 61-65 - [Електронне джерело]. - Режим доступу: http://ekmair.ukma.edu.ua/bitstream/ handle/123456789/9876/Nahnichuk_Pravova pryroda.pdf? sequence $=1$

7. Нагнічук О. I. Свобода вираження поглядів щодо державних службовців у рішеннях Європейського суду з прав людини [Текст] / О. I. Нагнічук // - Держава і право. Юридичні і політичні науки - 2014. - Вип. 64. - С. 345-351. - [Електронний ресурс]. - Режим доступу: http://nbuv.gov.ua/jpdf/dip_2014_64_51.pdf

8. Опришко $\lambda$. «Ограниченные» публичные люди. [Текст] / $\lambda$. Опришко // - Юридическая практика. - [Електронний pecypc]. - Режим доступу: http://pravo.ua/ article.php?id $=10005217$

9. Про запобігання та протидію легалізації (відмиванню) доходів, одержаних злочинним шляхом, фінансуванню тероризму та фінансуванню розповсюдження зброї масового знищення: Закон України від 06.12.2019 № 361-IX (пп. 37, 47 ст. 1). - [Електронний ресурс]. - Режим доступу: https:// zakon.rada.gov.ua/laws/show/361-20\#n831

10. Про судову практику в справах про відшкодування моральної (немайнової) шкоди: Постанова Пленуму Верховного Суду України від 31.03.1995 №4. - [Електронний pecypc]. - Режим доступу: https://zakon.rada. gov.ua/laws/show/v0004700-95\#Text

11. Словник української мови. Академічний тлумачний словник української мови: в 11 томах. - Том 8, 1977. - Стор. 383. [Електронний ресурс]. - Режим доступу: http://sum.in.ua/s/publichnyj

\section{Pegepam}

У статті досліджуються межі, якими визначається та обмежується публічність фізичної особи. Відзначається, що визначення змісту поняття публічної фізичної особи може варіюватися залежно від виконання нею тих чи інших функцій, зокрема, обіймання певних державних посад, виконання державницьких функцій, або ж посідання певного місця у суспільстві, що обумовлене здійсненням такою особою певного виду діяльності, що не пов'язана із державними інтересами (публічна діяльність, політична, співацька, акторська тощо).

Аналізується зміст поняття «широта впливу» публічної фізичної особи на публічну думку, а також зміст інших категорій, наявність яких дозволяє надати особі статус публічної. Зокрема, такі, як «широка відомість», «вплив на суспільну думку», «суспільна зацікавленість фізичною особою» тощо.

Визначення цих понять дозволить відмежувати статус публічних осіб від тих осіб, діяльність яких хоча, на перший погляд, можливо, і має ознаки публічної, проте не $\epsilon$ такою в повному розумінні. Зокрема, це стосується вчителів, викладачів вищих навчальних закладів, лікарів та інших осіб, що 


\section{АНОТАЦІЯ}

у статті досліджуються межі, якими визначається публічність фбізичної особи. Вбачається, що визначення змісту поняття публічної фбізичної особи може варіюватися залежно від виконання нею тих чи інших бункиій, зокрема, обіймання певних державних посад, виконання державницьких функиій, або ж посідання певного місия у суспільстві, що обумовлене здійсненням такою особою певного виду діяльності, що не пов'язана із державними інтересами (публічна діяльність, політична, співацька, акторсъка тощо).

Аналізується зміст поняття «иирота впливу» публічної фбізичної особи на публічну думку, а також зміст інших категорій, наявність яких дозволяе надати особі статус публічної. Зокрема, такі, як «широка відомість», «суспільна зачікавленість фбізичною особою» тощо. У заключній частині автор, залежно від змін в означених критеріях, пропонує виділити такі категорії публічних брізичних осіб, як «умовно публічна» та «справд $i$ публічна».

не підпадають під визначення, надані у перелічених вище нормативних актах та судових рішеннях, проте коло їх спілкування в процесі здійснення діяльності є досить широким, внаслідок чого вони можуть як впливати на формування думки широкого кола осіб, так і їхне життя або діяльність може викликати зворотню зацікавленість.

У ході роботи автор доходить висновку, що основним критерієм, що об'єднує в даній класифікації всіх перелічених осіб є критерій досить «широкої відомості», яка не передбачає особистого знайомства таких осіб із усіма особами, на яких вони «чинять

\section{SUMMARY}

The article examines the limits that determine the level of publicity of public individual.

It seems that the definition of the content of the concept of a public individual may vary depending on the performance of certain functions, in particular, the occupation of certain public positions, the performance of public functions or the occupation of a certain place in society, which is due to the implementation of a certain type of activity by such a person, is not related to state interests (public activities, political, singing, acting, etc.).

The content of the concept «breadth of influence» of a public individual on public opinion is analyzed, as well as the content of other categories, the presence of which allows to give the person the status of a public one.

In particular, such as «wide popularity», «influence on public opinion», "public interest to the individual» and others. In the final part the author depending on the changes in these conditions proposes to distinguish such categories of public individuals as «conditionally public» and «really public».

вплив» або у яких «викликають зацікавленість».

Особа ж, коло впливу якої, ступінь відомості, а також зацікавлених нею інших осіб потенційно можливо окреслити або навіть визначити поіменно, хай навіть їх і буде багато (наприклад, коло впливу вчителя або викладача умовно можна окреслити його учнями або студентами, коло впливу лікаря - пацієнтами тощо) може бути визначена як «умовно публічна», оскільки справжня публічність, виходячи з проаналізованих у статті положень, передбачає невизначеність кола осіб. 